\title{
What Is Neuroentrepreneurship? The Theoretical Framework, Critical Evaluation, And Research Program
}

\author{
DOI: $10.26466 /$ opus.840936
}

\author{
Arzu Girișken* - Tuna Çakar ** \\ * Dr. Öğr. Üyesi, Altınbaş Üniversitesi, İşletme Fakültesi, İstanbul/Türkiye \\ E-Mail: arzu.cakar@altinbas.edu.tr \\ ORCID: $\underline{0000-0003-0295-7976}$ \\ **Dr. Öğr. Üyesi, MEF Üniversitesi, Mühendislik Fakültesi, İstanbul/Türkiye \\ E-Mail cakart@mef.edu.tr \\ ORCID: 0000-0001-8594-7399
}

\begin{abstract}
As interest in entrepreneurship research to identify the possible economic development opportunities that entrepreneurs can provide, entrepreneurship research's objective tools are reaching their limits. Researchers in entrepreneurship are striving to discover new techniques and methodologies to answer questions about what makes a person an entrepreneur and perhaps identify and encourage an entrepreneur in the next step. Although a great deal of research has been done to answer these questions scientifically, traditional techniques have failed to produce the desired answers. For this reason, researchers working in the entrepreneurship field have recently been increasingly interested in applying neuroscience methods, especially after the proliferation of research fields such as neuroeconomics, neuromarketing, and neuropolitics. Although the population of neuroentrepreneurship research is gradually increasing, we cannot say that the field has been studied theoretically enough yet. In this article, a theoretical definition of neuroentrepreneurship is made, and a scientific framework is tried to be gained on the way to future research.
\end{abstract}

Keywords: Neuroentrepreneurship, Management, Entrepreneurship, Innovation, Neuroscience

JEL Classification: $\quad$ M00, M13, M16 


\title{
Nörogirişimcilik Nedir? Teorik Çerçeve, Kritik Değerlendirme ve Araştırma Programı
}

\begin{abstract}
Öz
Girişimcilerin sağlayabileceği olası ekonomik kalkınma fırsatlarım belirlemek için girişimcilik araştırmalarına ilgi arttıkça, girişimcilik kavrramını araştırmak için uygulanan nesnel araçlar sınırlarına ulaşıyor. Girişimcilik konusunda araştırma faaliyetlerinde bulunanlar, bir kişiyi hangi unsurların girişimci yaptığna ve belki de bir sonraki adımda bir girişimcinin nasıl belirlenip teşvik edilebileceğine dair cevaplanmamış sorulara yant bulabilmek için yeni teknikler ve metodolojiler keșfetmek adına gayret ediyorlar. Bu sorular bilimsel olarak cevaplamak için çok sayıda araştırma yapılmasına rağmen, geleneksel teknikler istenen cevapları üretmekte yetersiz kalmıştır. Bu nedenle, girişimcilik alanında çalışmalar yapan araştırmacilar son zamanlarda, özellikle nöroekonomi, nöropazarlama ve nöropolitika gibi araştırma alanlarının yaygınlaşmasından sonra, nörobilimin bu alanda sagladığ teknikleri uygulamaya giderek alana daha fazla ilgi gösteriyorlar. Nörogirișimcilik araştırmaları popülaritesi giderek artsa da, alan henuz̈ teorik olarak yeteri kadar çalışılmış diyemeyiz. Bu makalede, nörogrişimciliğin teorik bir tanımı yapılarak gelecek araştırmalara giden yolda bilimsel bir çerçeve kazandırılmaya çalışılmıştır.
\end{abstract}

Anahtar Kelimeler: Nörogirişimcilik, Yönetim, Girişimcilik, İnovasyon, Nörobilim JEL Sinıflandırması: $\quad$ M00, M13, M16 


\section{Introduction}

Entrepreneurship has been accepted for organizational sciences since the 1980s (Perez-Centeno, 2018). The phenomenon has already been investigated from a widely various perspectives via different approaches. Turcan and Fraser (2018) have attempted to identify the interconnections of entrepreneurship research with a total of more than twenty fields ranging from psychology and neuroscience to theology and philosophy. The promise of interdisciplinary research, particularly bringing neuroscientists together with economists and organizational scientists, has gained special attention within the last decade. In parallel to the fast development of neuroscience tools, the applicationbased fields have emerged with high speed (Massaro, 2017). The methods used in cognitive neuroscience have been involved in consumer research and research on financial and organizational behavior and entrepreneurship research (Massaro, 2017). These methods have been tracked by researchers from various fields, including organizational sciences, professional managers, and others. This attention has resulted in the onset of a new concept called neuromanagement. The tools and methods adopted from neuroscience enabled the researchers to apply the neuromanagement approach from a professional perspective, including economic and managerial decision-making processes. Neuromarketing has emerged as the most widely known and fastestgrowing subfield of the neuromanagement approach. The application of neuroscience techniques in marketing research and marketing campaigns has shed light on many black boxes in consumer decision-making processes. It has produced much more valuable information (Satpathy, 2012).

Conventional entrepreneurship research approaches have sought to identify entrepreneurs' main characteristics, their distinctive features and the impact of external factors such as environment and culture on entrepreneurial behavior. However, entrepreneurial cognition or decision-making processes have long been evaluated as a black box (Day, Boardman, and Krueger, 2017). Following the rise of behavioral economics, the entrepreneurship field provided enough framework to investigate an entrepreneurial kind of mental processes. Kahneman and Tversky have initiated the related framework (1974)'s empirical studies on decision-making and their prospect theory (1979). On the other hand, there have been empirical studies related to unconscious processing and decision-making by Libet, Gleason, Wright, and Pearl 
(1983). With the help of advances in neuroscience methods, Kahneman (2003) provided crucial work on bounded rationality.

The researchers in organizational sciences have collaborated with neuroscientists to scientifically identify how entrepreneurs' brains work and how their neural mechanisms are different than others. This very young interdisciplinary field has been investigated by researchers from various fields and specializations (Aydin \& Irmis, 2018). As a recently but rapidly emerged field, neuroentrepreneurship has already focused on conscious and unconscious processes behind entrepreneurial behavior and propensity. The 'neuro approach' related to entrepreneurship research has targeted identifying the unexplained differences in individuals' entrepreneurial behaviors. These observed differences were related to persons from very similar origins, including region, education, and even family. Different layers have been proposed to explain the whole phenomena from cognitive to emotional and from local to global. In this realm, the research findings for understanding the factors related to the geographical, educational, demographic, and sociological differences were not satisfactory (Day, Boardman, and Krueger, 2017).

Albeit gaining relatively high popularity at a growing speed, this very young field of neuroentrepreneurship has yet to be explored to a limited extent. It should be scientifically defined and framed as an application-based research field. There are currently too few studies on the issue (Krueger and Day, 2010). Some of the main research questions in the entrepreneurship field have been related to investigating the entrepreneurial decision-making processes and understanding the potential factors associated with providing training to the entrepreneur candidates. This article attempts to give a theoretical definition of neuroentrepreneurship along with a theoretical framework supported by the existing research to enlighten the road to further study.

\section{Definition of Neuroentrepreneurship}

After a couple of decades of research, most of the entrepreneurship researchers provided a framework related to entrepreneurship's central concept as a mindset that could be regarded as common sense (Wuebker et al., 2017). However, defining the mindset concept and its measurement remains con- 
troversial (Day, Boardman, and Krueger, 2017). The mainstream neuroscientific methods offer to extend the entrepreneurship research to investigate a critical point, namely 'entrepreneurial mindset' (Moore, McIntyre, Lanivich, and Le-Vasseur, 2019). The neuroscientific techniques have recently been regarded as crucial tools to identify the deeper structures and processes operating under the entrepreneurial way of thinking and entrepreneurial behavior. Although it has been attempted to analyze from various perspectives, scientific research has yet to identify the intentions that make a person an entrepreneur and the drivers of the entrepreneurial intentions. Haynie, Shepherd, Mosakowski, and Earley (2010) describe the entrepreneurial mindset's essence as the ability to sense, acting and mobilizing under uncertainty.

Moreover, the neuroentrepreneurship research program has focused on using the desired tools to testify the currently accepted theoretical arguments on entrepreneurial behavior (Alivisatos et al., 2013). Past research on entrepreneurship seems to agree to understand the potential factors, including cognitive, emotional, biological, and genetic factors, to differentiate an entrepreneur from a non-entrepreneur. However, the current tools used by entrepreneurship research are not sufficient to adequately evaluate the mechanisms that exist in entrepreneurs' brains (or, in other words, the mental processes). As a result, a proper and sufficient means of scientific testing of these hypotheses is not possible with the current research tools. However, neuroscience tools and neuroentrepreneurship approach carry an exciting potential that could help testify the current hypothesis in the field and the potential of triggering dramatic changes in the current knowled ge on entrepreneurial behavior (Binder et al., 2017).

Many research fields in social sciences have massively adopted the recent advances in neuroscientific methods, and entrepreneurship researchers seem to lag. Holan (2014) argues entrepreneurship researchers were not as quick as expected in the process of adopting and using the neuroscientific methods actively for several reasons. One of the first reasons is related to the need for interdisciplinary research teams composed of different experts from various disciplines. In addition to this, both the complex nature of the human brain and the used technologies make it difficult to develop research projects. The last reason is the operational costs of using neuroscience techniques. Despite 
the barriers neuroentrepreneurship has, it can be claimed that these novel approaches will doubtlessly improve entrepreneurship knowledge. (Cummings and Nickerson, 2017).

Krueger and Welpe (2008) use neuroentrepreneurship to refer to the triad of neurosciences, entrepreneurship, and /entrepreneurial experiments and studies. On the other hand, Blair (2010) conceptualizes neuroentrepreneurship as a novel and interdisciplinary field that uses neuroscience, neuropsychology, and neuroeconomics to identify entrepreneurs' decisions and behaviors. Krueger and Welpe et al. (2014) attempts to define neuroentrepreneurship as the study of entrepreneurship behavior with the involvement of the methods related to cognitive neuroscience. The current attempts to clarify neuroentrepreneurship research provide a conceptual understanding related to the use of neuroscientific methods mainly for the identification of neural and mental processes related to entrepreneurs as opposed to non-entrepreneurs.

\section{Literature on Neuroentrepreneurship}

Lawrence, Clark, Labuzetta, Sahakian, and Vyakarnum (2008) have explored the differences between entrepreneurs' and managers' brains. Their findings indicated that both successful entrepreneurs and managers could have cold cognition or perform rational analysis. Still, entrepreneurs differed from managers with also using hot cognition or emotional thinking. The obtained results also showed that the neural activities related to cognitive and emotional processes occur in different brain locations. Still, both of these activities are regulated by the activation of the frontal lobes. Stanton et al. (2008) have questioned whether entrepreneurs make their decisions on a rational basis by employing neuroeconomics tools.

Zald et al. (2008) have shown that the entrepreneur's brain has a higher level of dopamine receptor density in the cerebral cortex as opposed to the non-entrepreneurs. The similar fact of having a higher number of dopamine receptors is also valid for risk seekers' brains. According to Stanton and Welpe (2010), risk perception and the related factors could be accepted as one of the most suitable grounds for neuroentrepreneurship since the findings in the literature indicate that the brains' responses to risk are different. Their fMRI analysis has illustrated that specific brain regions, including anterior 
cingulate and lateral orbitofrontal cortices, or inferior frontal gyrus, striatum, and insula, are triggered by the risk-related stimuli. In addition to this, the neuroscientific findings in the literature indicate that there are brain regions such as the orbitofrontal cortex, inferior frontal gyrus, amygdala, and insula that are activated for situations related to uncertainty and ambiguity. Holan, Ortiz-Teran, Turrero, and Tomas (2013) have also claimed that the adopted methods and tools from the neuroscientific literature will contribute to entrepreneurship research. This neuro-oriented approach examines the cortical organization differences between entrepreneurs by using a control group composed of non-entrepreneurs. Their empirical study has already employed event-related potential (ERP) methodology to explore the participants' brain activities given a simple task under emotional interferences. Their results suggested that the response to the emotional stimuli has occurred differently in the brains of entrepreneurs. Moreover, entrepreneurs were found to make their decisions more quickly, both behaviorally and neurologically. To sum up, entrepreneurs' brains process the obtained information differently while different brain areas tend to be activated.

Laureiro-Martinez et al. (2014) investigate the differences in brain activities of entrepreneurs and managers. The participants under fMRI were given an exploration and exploitation task. This experimental study's empirical findings indicated that entrepreneurs' brains are far more flexible in different cognitive functions, including attention disengagement, pattern switching, and evidence tracking that are crucial for effective decision-making processes. Krueger and Welpe (2014) have questioned what entrepreneurship researchers would learn from neuroscience to identify the potential deeper antecedents of entrepreneurial behavior. They promote the differences between automatic and intentional processing by which they also argued for the intersectional areas for fluid intelligence, change blindness, and mental prototypes. They suggest that decision-making processes could be treated as rather than intentionally triggered processes but more automatic and unconscious processes in this realm. The identification of the potential unintentional process has been the main impasse here. Thus, they focus on identifying the intentional decision-making process related to entrepreneurship to overcome this deadlock. For mental prototypes, they suggest those who evaluate entrepreneurship as a self-identity are more likely to succeed in entrepreneurship. They also propose the working memory as a critical leverage role for different 
tasks, including problem-solving, as a part of fluid intelligence. At the same time, they relate the ability to identify opportunities and threats laying ahead of an entrepreneurial process with the change blindness.

Zaro, Fagundes, Rocha, and Nunes (2016) investigate the differences between the brains of entrepreneurs and non-entrepreneurs via the EEG method during the process of identifying an investment opportunity. This empirical study suggests that there are differences between entrepreneurs and non-entrepreneurs in the evaluation of financial risk. This study's findings showed that the bilateral activation takes place among the frontal cortices for entrepreneurs as opposed to non-entrepreneurs, specifically during the search and discovery of opportunities and the propensity to take risks to explore. Drover, Cerf, and Shane (2016) perform an fMRI study to investigate the inner working principles of the black box how an equity investor's brain responds neurologically to pitches by entrepreneurs on 20 investors. This study aims to understand the neural reactions to variations in entrepreneurial processes with a hypothesis suggesting that pitches would trigger neural processes in different regions of the brain depending on the level of displayed entrepreneurial enthusiasm.

\section{Further Research}

Since neuroeconomics has focused on identifying the neural processes related to economic decision-making and the related factors, neuroentrepreneurship research has attended the neural processes regarding entrepreneurship. Neuroeconomics researchers also worked on more computational and classification models (Konovalov and Krajbich, 2016).

Another critical issue with respect to the research framework related to the neuroentrepreneurship is that the neuroscientific methods should not be regarded in a revolutionary sense that they will place the conventional methods including laboratory experiments, self-reporting, or interviews; however, the primary approach should be having both of the methods, and these will be used in a complementary fashion (Holan, 2014). Moreover, the research questions related to entrepreneurial identity and intentions have also been associated with the memory-related brain areas through priming and procedural learning (Welpe et al., 2012). On the other hand, the development of self-iden- 
tity has been related to the development of entrepreneurial identity and intentions, which could be investigated for the neuroscience methods and autobiographical memory domain. This approach supported by the autobiographical memory perspective will contribute to understanding the previous experiences while becoming an entrepreneur. On the other hand, cognitive neuroscience has focused on investigating the brain of an entrepreneur while trying to model the cognitive structures as well as the neural correlations of the entrepreneurial mindset that probably have the main role of forming the entrepreneurial identity. The perspective of applied cognitive neuroscience on entrepreneurship enabled a set of different hypotheses that caved the path for overcoming the current obstacles within the conventional research domain. Neuroentrepreneurship researchers use MEG (Magnetoencephalography), PET (Positron emission tomography), EEG (Electroencephalography), fMRI (Functional magnetic resonance imaging), and fNIRs (Functional near-infrared spectroscopy) as tools in neuroimaging and neuroscientific methods. Bentzen (2018) considers fMRI among the other methods mentioned above as the most relevant and informative technique. fMRI is an expensive method, and it requires expertise to properly apply along with its other weaknesses, such as the temporal resolution. However, it underlines that it is not dependent on prior cognitive processing and, as a result, it is helpful to identify unconscious processes. On the contrary, Holan and Couffe (2017) suggest that EEG appears as the highest promise confronted with its high temporal resolution despite its limited spatial resolution. Centeno (2017) identifies a total of seven neuroscience methods by which the entrepreneurship research projects could be carried out, including EEG, MEG, fMRI, fNIRs, TMS (Transcranial magnetic stimulation), tDCS (transcranial direct current stimulation), and neurofeedback. Centeno (2017) also argues that these neuroscientific methods provide a means for nurturing and augmenting entrepreneurial behavior as a part of the research framework related to entrepreneurship. Each of these methods contains different strengths and drawbacks. It is the consensus that the most relevant method can be determined for the research questions, hypotheses, and the project budget.

Hoskisson, Covin, Volberda, and Johnson (2011) develop various research ideas and questions for which the neuroscientific methods could be used. The fundamental approach is to determine the potential factors related to identifying an opportunity by an entrepreneur. Proper identification of this process 
in an entrepreneur's brain would be invaluable to expand the entrepreneurial behavior. However, it currently seems impossible since neuroscience has yet to identify all neural strategies that work in the human brain. Another idea for research could be to determine whether an entrepreneur's brain shows some highly distinct neural patterns. This is one of the main dilemmas that entrepreneurship literature has faced so far. Many researchers have proposed that a successful entrepreneur is not required to be more intelligent. Still, she should have some pathological focus on the venture to make it successful, although this argument has yet to be proven (Antshel, 2018).

Another critical discussion in entrepreneurship literature is on whether a successful entrepreneur can identify opportunities or the ability to set the required organization to satisfy from a chance or just the pathological bias to focus on success (Fayolle and Linan, 2014). Neuroentrepreneurship tools also offer the potential to identify this question as each recognition of an opportunity or organization of resources, or pathological focus are linked to different brain regions, different neural pathways/circuits, and different skills obtained by the brain (Baucus \& Baucus, 2017). Moreover, entrepreneurship research has yet to identify whether entrepreneurs have better skills to reason or are just better at seducing people. The answer could be both, although the question remains unanswered (Holan, 2014).

Within the related academic literature on neuroentrepreneurship research, a novel research idea could be developed to find an answer for the question of whether entrepreneurs brain work as similar to the brains of pathologically obsessive people since neuroscience has already gained sufficient information/knowledge gathered through evaluating brains of obsessive people. Information collected from neural processes occurring in the brains of entrepreneurs during entrepreneurial decision-making could also be compared to other brains that have already been gathered by neuroscientists such as geniuses. It is also highly interesting to provide a research framework with respect to how geographical factors and/or cultural differences might affect entrepreneurs' brains. Albeit its expensiveness, fMRI could be accepted as the most preferred neuroimaging technique. Teamwork that would also include neuroscientists would be more helpful in dealing with the complications of neuroscience. 


\section{Criticism}

Bentzen (2018) argues that neuroentrepreneurship will be contributing to the entrepreneurship research domain. However, the contribution will not be in a revolutionary sense, however, bioentrepreneurship will probably be providing a more comprehensive framework for modeling entrepreneurial behavior. This view could be assessed in terms of the nature of scientific methodology in which there is no guarantee for the revolutionary developments before its conduction. Meanwhile, bioentrepreneurship mainly focuses on promoting scientific or biotechnological innovations in entrepreneurship rather than identifying the entrepreneurial decision-making process for training entrepreneur candidates. Moreover, neuroentrepreneurship, when compared to the other fields related to the applied neuroscience like neuromarketing, would require a more complex level of experimental methodologies as well as include higher levels of limitations. Another view that the researchers from the other related domains like neuroeconomics and neuromarketing will be more careful about overcoming the potential mistakes with respect to their previous experience (Brannback and Carsrud, 2017).

The most significant limitation related to neuroentrepreurship research program initiates with the laboratory requirement by which the experimental studies could be conducted. As a result of this, there is an inevitable need for higher budgets to cover the potentially higher costs. Moreover, there are always the criticism related to performing the experiments under the laboratory environment to argue that the participants' behavioral and neural patterns might differ in the laboratory compared to natural circumstances. In addition to this, the limits related to the neuroscientific methods do directly apply to the neuroentrepreneurship research domain. Finally, there is also the risk of not identifying the main factors related to entrepreneurial processes as occurred priorly with respect to the identification of personality traits.

\section{Conclusion}

Neuroentrepreneurship has emerged as a popular interdisciplinary field that targets at identification of the entrepreneurial mindset. A sufficient identification and modeling of the entrepreneurial cognitive and neural processes will enable the researchers to suggest more efficient and effective decision- 
making processes that will pave the path for higher levels of success. Concerning the traditional approaches to entrepreneurial decisions, functional benefits have been prioritized, and the short-term benefits but generally not tested via scientific methodology. Since entrepreneurs are more likely to focus on their investments' short-term benefits, it is also critical to provide solutions ways to predict the long-term benefits by not being limited to shortterm benefits. It is expected that the neuroscientific approaches and methods might hopefully contribute to these decision-making processes for providing more profitable and sustainable outcomes, especially within a harsh competitive environment.

The applied neuroscience approaches, mainly including neuromarketing, generally address the customers' emotional dimension rather than long-term effects. There is a need for a shift to understand entrepreneurial decisionmaking processes in line with the literature's successful applications. Several good cases are provided by multinational companies such as BMW that made use of these entrepreneurial decisions successfully. The German carmaker, BMW, prioritized proposing solutions to the men having midlife troubles with elegant cars. Under the circumstances in which the global competition increases rapidly, it is crucial that the entrepreneurs shall learn about the cognitive and neural mechanisms that have a driving impact on their decisionmaking processes to develop their business much more successfully. Past researchers agree that most of the successful entrepreneurs tend to have intuitive and natal abilities. Hereby, a talented advertising specialist or a successful marketer can intuitively understand consumer needs. However, the neuroscientific methods have recently proposed more objective tools and methodology more appropriately. Neuroentrepreneurship researchers aim to apply similar methods to entrepreneurs to identify the processes working behind these intuitive decisions to help improve entrepreneurial success. A neuroscientific framework on entrepreneurial cognitive and neural processes as well as on how the entrepreneur's brain works and also how or whether the brain of an entrepreneur functions differently could be obtained through neuroentrepreneurship research, and this potential knowledge would be highly valuable to educate new entrepreneurs or to evaluate which entrepreneur would add more in the general welfare. 
In the last decade, neuroscientific tools and methods are used more widely at a growing pace. However, entrepreneurial cognitive and emotional processes are evaluated as a black box for the time being in spite of the work done in the academic literature. Neuroentrepreneurship research findings will hopefully provide new insights into these processes in the following decades. A proper understanding of entrepreneurial decision-making processes would have a crucial role for understanding and guiding the entrepreneurs in different sectors. As new brands and products are released each day, different marketing strategies and communication techniques are developed. Similarly under a very chaotic environment, entrepreneurial decisions are also highly affected, and entrepreneurs should come up with the most optimal decisions with respect to understanding the expectations of the potential or actual consumers. Thus, the expected outcomes from neuroscientific methods will contribute to identifying the cognitive constructs and neural correlations related to entrepreneurial decisions and cognitive strategies mainly to sustain the potential marginal benefit.

\section{Kaynakça / References}

Aydın, H. U. D., and Irmis, A. (2018). Looking deeper into entrepreneurship: Neuroentrepreneurship. Current Debates in Management \& Organization, 29, 237-249.

Alivisatos, A., Chun, M., Church, G., Deisseroth, K., Donoghue, J., Greenspan, R., and Yuste, R. (2013). Thebrain activity map. Science, 339, 1284-1285. doi: 10.1126/science.123693

Antshel, K. M. (2018). Attention Deficit/Hyperactivity Disorder (ADHD) and Entrepreneurship. Academy of Management Perspectives, 32(2), 486-503. doi: 10.5465/amp.2016.0144

Baucus, D. A., and Baucus, M. S. (2017). Opportunity Conception: An Analysis of Percept-Concept Structures in the Human Brain. Academy of Management Proceedings, 2014(1), 523-542. doi: 10.5465/ambpp.2014.12675abstract

Bentzen, J. S. (2018). Cognitive neuroscience perspective on entrepreneurship. (Chp.) The Palgrave Handbook of Multidisciplinary Perspectives on Entrepreneurship. Palgrave Macmillan: UK.

Binder, J. K., McBride, R., Sud, A., Wuebker, R. J., Krueger, N. F., Cesinger, B., .. Pereira, D. (2017). Is "Neuroentrepreneurship" Worth Pursuing?. Academy of Management Proceedings, 2015(1), 348-361. 
Blair, E. S. (2010). What you think is not what you think: unconsciousness and entrepreneurial behavior. (Chp.) Neuroeconomics and the Firm, Edward Elgard Publishing: UK.

Brannback, M., and Carsrud, A. L. (Eds.). (2017). Revisiting the entrepreneurial mind. Springer: Switzerland.

Centeno, V. P. (2017). Which tool should I use? Neuroscience technologies for braindriven entrepreneurship researchers. In Handbook of Research Methodologies and Design in Neuroentrepreneurship, Chapter 11, p.259-284, Edward Elgar Publishing.

Cummings, T., and Nickerson, J. A. (2017). An Exploration of Brain Science and its Potential Contributions to Strategic Management \& Thinking. Academy of Management Proceedings, 2017(1), 264-283. doi: 10.5465/AMBPP.2017.146

Day, M., Boardman, M. C., and Krueger, N. F. (Eds.). (2017). Handbook of research methodologies and design in neuroentrepreneurship. Cheltenham, UK: Edward Elgar Publishing.

Drover, W. Cerf, M., and Shane, S. (2016). The neuroscience of investor decision making: An fMRIStudy. Frontiers of Entrepreneurship Research, 36(1), 21.

Eagleman, D. (2011). Incognito: The secret lives of the brain. Pantheon Books: New York.

Eagleman, D. (2015). The brain: The story of you. Canongate Books: UK.

Fayolle, A., and Linan, F. (2014). The future of research on entrepreneurial intentions. Journal of Business Research, 67(5), 663-666. doi: 10.1016/j.jbusres.2013.11.024

Haynie, J. M., Shepherd, D., Mosakowski, E., and Earley, P. C. (2010). A situated metacognitive model of the entrepreneurial mindset. Journal of Business Venturing, 25(2), 217-229. doi: 10.1016/j.jbusvent.2008.10.001

Holan, P. M., Ortiz-Teran, P., Turrero, E. A., and Tomas, A. O. (2013). Towards neuroentrepreneurship? Early evidence from a neuroscience study. Frontiers of Entrepreneurship Research, 33(5), 12.

Holan, P. M. (2014). It's all in your head: why we need neuroentrepreneurship. Journal of Management Inquiry, 23(1), 93-97. doi: 10.1177/1056492613485913

Holan, P. M., and Couffe, C. (2017). Unpacking neuroentrepreneurship: conducting entrepreneurship research with EEG technologies. In Handbook of Research Methodologies and Design in Neuroentrepreneurship, Chapter 4, p.94-119 Edward Elgar Publishing.

Hoskisson, R., Covin, J., Volberda, H., and Johnson, R. (2011). Revitalizing entrepreneurship: The search for new research opportunities. Journal of Management Studies, 48, 1141-1168. doi: 10.1111/j.1467-6486.2010.00997.x 
Kahneman, D. and Tversky, A. (1979) Prospect model: an analysis of decisions under risk. Econometrica, 47, 262-291.

Kahneman, D. (2003). A perspective on judgment and decision making: mapping bounded rationality. Am. Psychol. 58, 697-720. doi: 10.1037/0003-066X.58.9.697

Konovalov, A., and Krajbich, I. (2016). Over a decade of neuroeconomics: What have we learned?. Organizational Research Methods, 1-26. doi: $10.1177 / 1094428116644502$

Krueger, N., and Welpe, I. (2008). Experimental entrepreneurship: A research prospectus and workshop. Working paper, USASBE Annual Conference, San Antonio.

Krueger, N., and Day, M. (2010). Looking forward, looking backward: from entrepreneurial cognition to neuroentrepreneurship. In Handbook of Entrepreneurship Research, Springer: New York.

Krueger, N. and Welpe, I. (2014). Neuroentrepreneurship: what can entrepreneurship learn from neuroscience?. Annals of Entrepreneurship Education and Pedagogy.

Laureiro-Martinez, D., Canessa, N., Brusino, S., Rollo, M., Hare, T., Alemanno, F., and Cappa, S. E. (2014). Frontopolar cortex and decision-making efficiency: comparing brain activity of experts with different professional background during an exploration-explotaition task. Frontiers in Neuroscience, 7(927), 1-10. doi: 10.3389/fnhum.2013.00927

Lawrence, A., Clark, L., Labuzetta, J., Sahakian, B., and Vyakarnum, S. (2008). The innovative brain. Nature, 456(7219), 168-169. doi: 10.1038/456168a

Libet, B., Gleason, C., Wright, E., and Pearl, D. (1983). Time of conscious intention to act in relation to onset of cerebral activity: unconscious initiation of a freely voluntary act. Brain, 106, 623-642.

Massaro, S. (2017). Neuroscience methods: Promising tools to advance organizational research on affect. Academy of Management Proceedings, 2014 (1), 276-291. doi: 10.5465/ambpp.2014.12260abstract

McBride, R. (2014). Toward a study of neuroentrepreneurship. Working paper, Annual Academy of Management Conference, Philadelphia.

Moore, C., McIntyre, N. H., Lanivich, S. E., and Levasseur, L. (2019). ADHD and the Entrepreneurial Mindset. Academy of Management Proceedings, 2019(1), 187-206. doi: 10.5465/AMBPP.2019.11086abstract

Perez-Centeno, V. (2018). Brain-driven entrepreneurship research: Expanded review and research agenda towards entrepreneurial enhancement. Working Paper, No. 02/18, Institut für Mittelstandsforschung (IfM) Bonn, Bonn.

Satpathy, J. (2012). Issues in neuro: Management decision making. International Journal of Business Management, 2(2), 23-36. 
Stanton, A., Day, M., Krueger, N., Welpe, I., Acs, Z., and Audretsch, D. (2008). The questions (not so) rational entrepreneurs ask: decision-making through the lens of neuroeconomics. Working paper, Academy of Management Conference, Anaheim.

Stanton, A, and Welpe, I. (2010). Risk perspectives in entrepreneurial research. In Neuroeconomics \& the Firm. Cheltenham UK: Edward Elgar.

Turcan, R. V., and Fraser, N. M. (2018). The Palgrave handbook of multidisciplinary perspectives on entrepreneurship. Palgrave Macmillan: UK.

Tversky, A., and Kahneman, D. (1974). Judgment under uncertainty: heuristics and biases. Science, 185, 1124-1131. doi: 10.1126/science.185.4157.1124

Tversky, A., and Kahneman, D. (1979). Prospect theory: An analysis of decision under risk. Econometrica, 47(2), pp. 263-291.

Welpe, I. M., Spörrle, M., Grichnik, D., Michl, T., and Audretsch, D. B. (2012). Emotions and opportunities: The interplay of opportunity evaluation, fear, joy, and anger as antecedent of entrepreneurial exploitation. Entrepreneurship Theory $\mathcal{E}$ Practice, 36, 69-96. doi: 10.1111/j.1540-6520.2011.00481.x

Wuebker, R. J., Krueger, N. F., Belousova, O., Costa, S. F., Day, M., Frederiks, A., .. McBride, R. (2017). In search of the "entrepreneurial mindset": Insights from Neuroscience. Academy of Management Proceedings, 2014 (1), 453-469. doi: 10.5465/ambpp.2014.15052symposium

Zald, D. H., Cowan, R. L., Riccardi, P., Baldwin, R. M., Ansari, M. S., Li, R., and Kessler, R. M. (2008). Midbrain dopamine receptor availability is inversely associated with novelty-seeking traits in humans. Journal of Neuroscience, 28(53), 14372-8. doi: 10.1523/JNEUROSCI.2423-08.2008

Zaro, M. A., Fagundes, L. C., Rocha, F. T., and Nunes, W. C. (2016). Cognitive brain mapping used in the study of entrepreneurial behavior: Pilot test with the use of electroencephalogram - EEG during the Process of Identification of Business Opportunities. American Journal of Educational Research, 4(6), 472-478. doi: 10.12691/education-4-6-5 


\section{Kaynakça Bilgisi / Citation Information}

Girişken, A. and Çakar, T. (2021). What is neuroentrepreneurship? The theoretical framework, critical evaluation and research program. OPUS-International Journal of Society Researches, 17(36), 2975-2991. DOI: 10.26466/opus.840936 